\title{
Erosion processes initialized by use of heavy equipment in mountain forests of the Wilczy Potok catchment, Silesian Beskids
}

\author{
Włodzimierz Łukasik*, Piotr Kubiesa, Tomasz Staszewski \\ Institute for Ecology of Industrial Areas, Poland \\ *Corresponding author's e-mail: luk@ietu.katowice.pl
}

\begin{abstract}
Keywords: mountain forest, skidding, soil erosion, erosion gullies, forest management.
Abstract: Forest stand decomposition of the Silesian Beskids which is followed by the tree cutting has been observed since the beginning of the $21^{\text {st }}$ century. Changes in forest management due to the introduction of heavy machines for forest work mainly for skidding have been observed in the Silesian Beskids for the last decade. The paper presents results of a three-year investigation of erosion gullies forming in mountain forest after the skidding performed with use of heavy equipment. In the Wilczy Potok catchment comprising an area of above 100 ha 40 gullies were identified. The measurement of the length and depth of gullies showed that the total volume of soil and rock material removed from the catchment area due to erosion accelerated by skidding exceeded $9000 \mathrm{~m}^{3}$. The year erosion rate for deep gullies was found to be $10 \%$. The presented results show that necessary protective actions and preventive measures should be taken to mitigate the soil degradation processes.
\end{abstract}

\section{Introduction}

Among many forest ecosystem services the protection function of mountain forests seems to be of great importance. Their role increases along with the intensity of biotic and abiotic adverse stresses occurring presumably owing to climatic changes, such as weather anomalies, increased pest attacks and improper management practices (Bytnerowicz et al. 1999).

Most of the mountain forests located in the southern Poland have the status of soil protection forests. Moreover, most of Polish rivers have their sources in the mountain areas. Changes in the retention capacity of mountain forests begin to be a problem not only for foresters but also for the local community due to the lack of drinking water. This is the reason why mountain forests in the southern Poland are classified as water protection forests.

The Silesian Beskids belong to the Polish part of the West Carpathians. Spruce contributes in $74.4 \%$ to the 40,500 ha area of forests in the Silesian Beskids.

In the Silesian Beskids, due to several successive years of droughts followed by the bark beetle gradation, the spruce forest dieback was observed. It is assumed that within 15 years all spruce trees will be cut down in that area. This situation needs the stand reconstruction, which is assessed to comprise 5500 ha, in the period of 10 years. Forest stand decomposition is followed by the sanitary cuttings. In Poland the forwarding and along-the-ground skidding are the most popular methods of wood extraction. The horse skidding which was traditionally used in the mountain areas has not caused so drastic changes in water/soil environment (one horse could pull one or two logs). Heavy tractors, such as LKT, are currently used in the whole mountain region and they can pull several spruce logs at the same time. Such activities lead to intensive erosion gully formation.

Soil erosion involving gullies is one of the major causes of land degradation worldwide and a global threat to forestry productivity (Gyssels et al. 2005). The gullies are permanent incisions in the landscape and, depending on location, are responsible for $10 \%$ to $94 \%$ of the total sediment yield caused by water erosion in the world (Poesen et al. 2003). The negative effects of soil erosion include water pollution, crop yield depression, organic matter, suspended and dissolved material loss from the ecosystem, and reduction in water storage capacity (Bakker et al. 2004, Boardman and Poesen 2006, Stavi et al. 2010).

The clearing of vegetation (Zheng et al. 2005), cultivation (Gyssels and Poesen 2003, Valentin et al. 2005) or overgrazing (Moir et al. 2000) are mentioned as anthropogenic causes of gully formation. The protection of soil resources has therefore been recognized as an important objective of environmental policy (CEC, 2006): this requires correct erosion rate assessment (Cerdan et al. 2010).

The aim of this paper is to assess the effect of skidding with use of heavy equipment on soil erosion processes in the mountain area.

The investigation carried out in the catchment consisted of three parts: identification of the gullies, measurement of the section (depth of gullies), and calculation of the erosion rate. 


\section{Methods}

\section{Investigation Area}

Investigation was carried out in the catchment of the Wilczy Potok Valley in Brenna, the Silesian Beskids (49 40'07" N, $\left.18^{\circ} 56^{\prime} 37^{\prime \prime} \mathrm{E}\right)$ in 2010-2012. The catchment area of 138 ha at the elevation of $750 \mathrm{~m}$ a.s.l. is covered with spruce monoculture. Slope steepness amounts to $13^{\circ}$.

The soil is developed of the Carpathian Flysch, Godulska series, is classified as Albic Cambisol and the soil textural groups are as follow: 0-40 cm - sandy loam, and 40-160 cm medium and heavy stony loam (RDLP Katowice 2014). Mean annual temperature and rainfall for the last decade were $8.8^{\circ} \mathrm{C}$ and $1084 \mathrm{~mm}$, respectively.

\section{Identification of the gullies}

Inventory of the gullies was performed using a GPS receiver. After finding the gully a starting point was marked followed by consecutive points every $10 \mathrm{~m}$ (shallow gullies) and $25 \mathrm{~m}$ (deep gullies). The course of the gullies was recorded as a "path" in the GPS receiver which made it possible to put them on topographic maps.

\section{Establishing and measurements of erosion gullies sections}

Observation of the erosion processes and their rate should be carried out on permanent sections. Gully sections are marked out by two benchmarks (steel rods) plunged into the soil. Next, the tape measure is stretched between the rods. Each section (course of the tape) should be selected in the same way to facilitate their identification in the field. These "zero points" which can be big stones, studs or thick tree roots should be localized $50 \mathrm{~cm}$ from the gully edge (Fig. 1a). The next step is determination of the gullies depth. Measurement is made using a metallic measurement tape whose end is loaded with $50 \mathrm{~g}$ weight. This tape is moved along the tape stretched between benchmarks and lowered so that its loaded end could reach the gully bottom. First measurement is made in the "zero point" towards the main axis of the gully and the last one in the opposite "zero point". The depth is recorded as $\mathrm{Y}_{\mathrm{i}}$ whereas localization on the horizontal tape as $\mathrm{X}_{\mathrm{i}}$ (Fig. 1b). Such measurement allows for calculating a cross-sectional area of the gully through adding up the area of trapezoids (Fig. 2). Joining the corresponding individual trapezoids with trapezoids of the next section one can obtain a solid (Fig. 3),

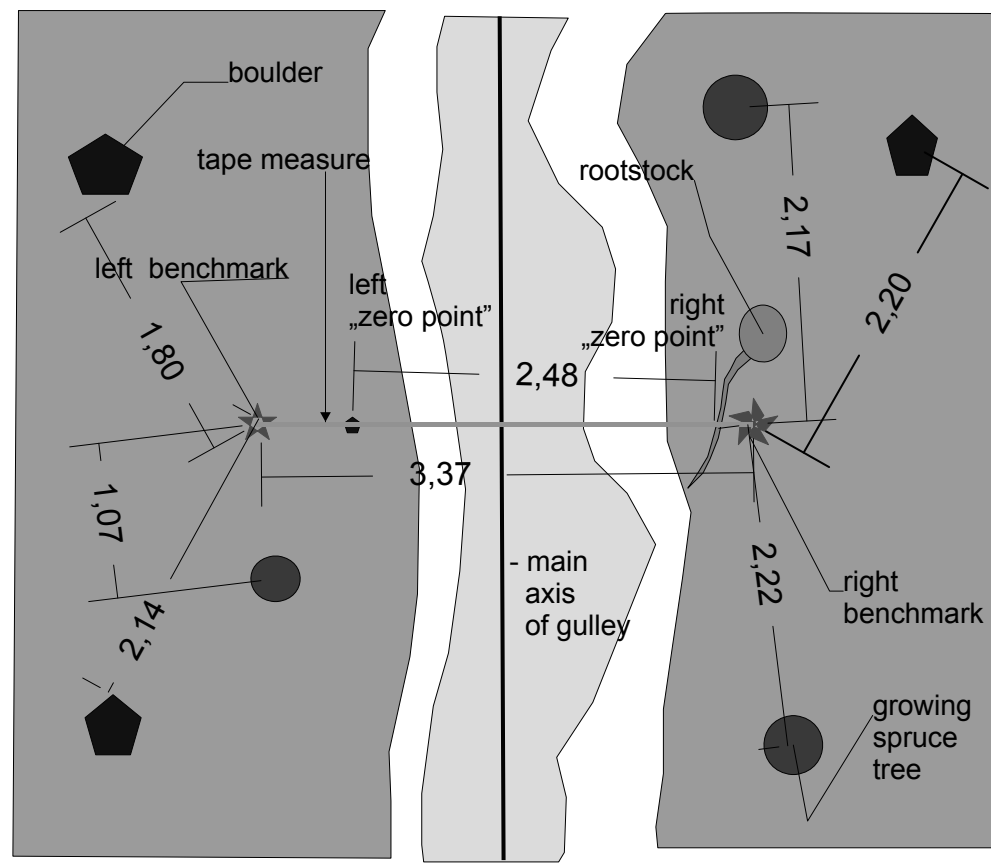

A.)

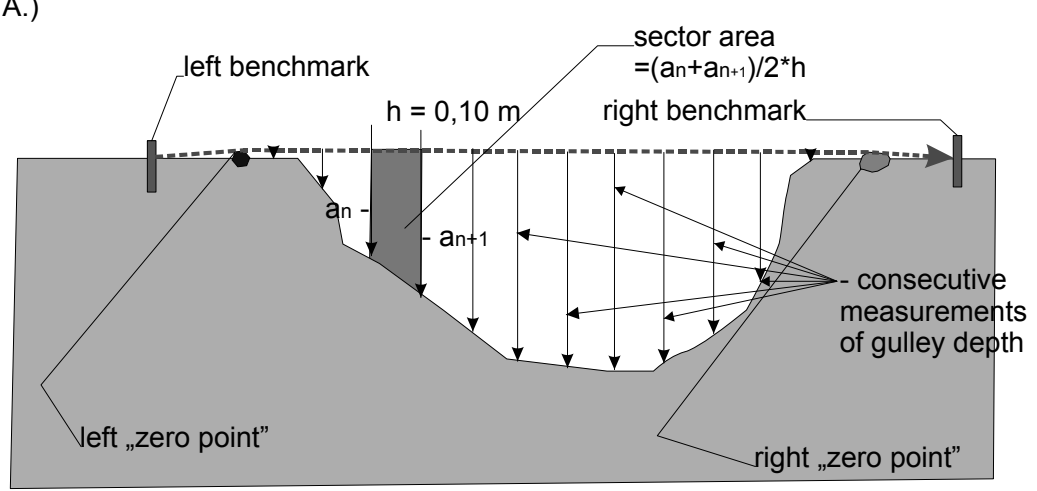

B.)

Fig. 1. Installation of benchmarks and measurements of gully cross sections 


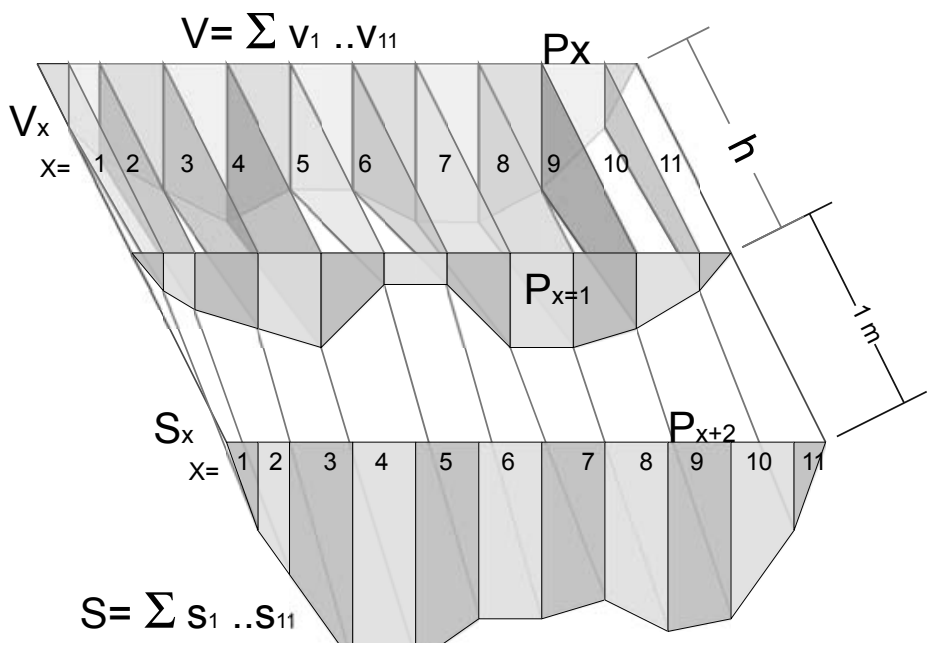

Volume of gulley 1 running meter $=$ $=$ volume of segment between $P x$ and $P x+1$ sections divided by distance (in meters) between these sections

Fig. 2. Measurement of the erosion gully fragment volume between consecutive sections

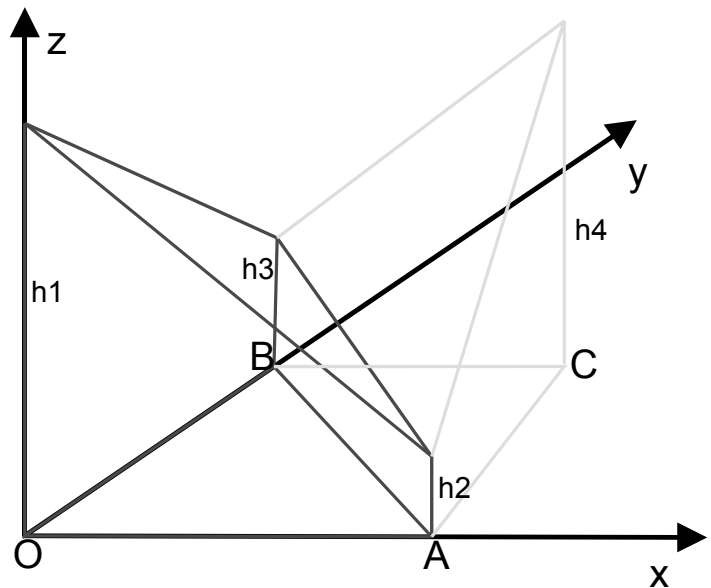

Fig. 3. Elementary segment of erosion gully for the volume calculation

the volume of which is calculated according to the following equation:

$$
V=\int_{\triangle O A B} f(x, y) d x d y+\int_{\triangle C B A} f_{2}(x, y) d x d y
$$

So the total volume of the gully segment between the successive sections is a sum of solids volume formed in the way described above.

\section{Field measurements}

In 2006 on slopes of the Wilczy Potok Valley the high level of trees defoliation was observed. In the same year cutting of forest stand has begun. The logs cut were skidded using LKT80 and LKT81 tractors; this was organized along the line which had not been used as a skidding route before.

In 2010 an inventory of erosion gullies was carried out. In 2011, on 5 gullies - R14, R16, R19, R21 and R18 of "W" type which were formed as a result of the overhead skidding the measurement sections were established. Such sections were also established on R34 gully which was the only "V" gully type found in the catchment area formed by the alongthe-ground skidding. Data from this gully were not included in the analysis and measurements were performed to compare environmental consequences of horse and tractor skidding.

\section{Calculation of the erosion rate}

In 2011, on two deep gullies (R14 and R16) and on one shallow gully (R19) the measurement sections were established to determine the erosion rate.

\section{Results and discussion}

Within the investigated catchment, 40 erosion gullies formed due to skidding were registered (Fig. 4). In total the length of all identified gullies amounted to $10,198 \mathrm{~m}$ (Tab. 1). The longest one was 1,327 meters long (R5 + R13) followed by R1 - 828 m long (Tab. 1).

Individual ride of a LKT heavy tractor leaves a "trace" of 2 $m$ width. However, the dragged logs cause the widening of the gully. Further gully widening results from erosion of its edges. In the catchment area the width of gullies ranged from $2.5 \mathrm{~m}$ to $5.10 \mathrm{~m}$, giving mean value of $3.5 \mathrm{~m}(\mathrm{n}=123)$. Assuming such 


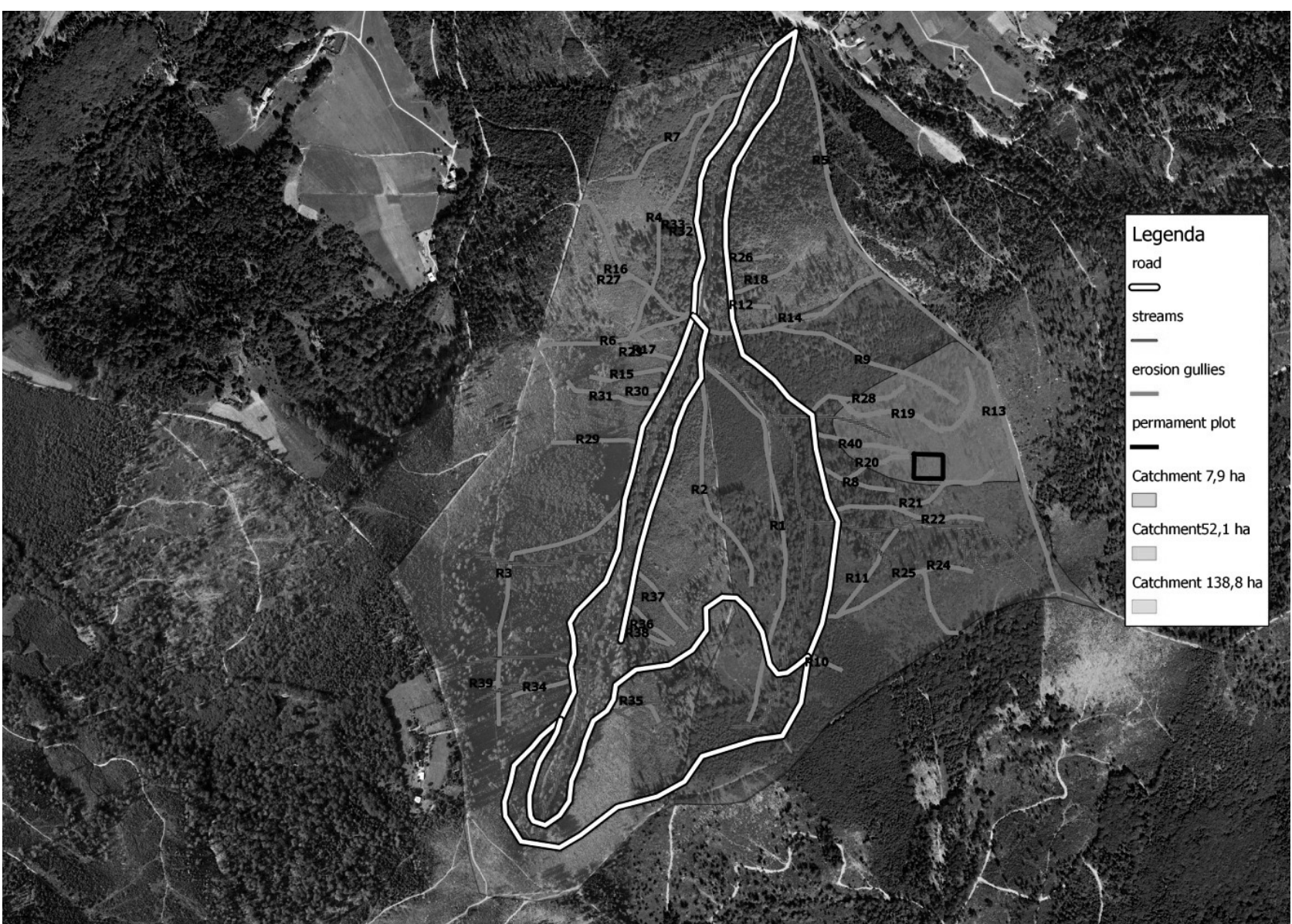

Fig. 4. Gullies in the Wilczy Potok catchment in Brenna

Table 1. Parameters of the gullies

\begin{tabular}{|c|c|c|c|}
\hline Gully & $\begin{array}{l}\text { Length } \\
{[\mathrm{m}]}\end{array}$ & $\begin{array}{c}\text { Estimated } \\
\text { volume }\left[\mathrm{m}^{3}\right]\end{array}$ & $\begin{array}{c}\text { Measured } \\
\text { volume }\left[\mathrm{m}^{3}\right]\end{array}$ \\
\hline $\mathrm{R} 1$ & 828.3 & 755.6 & \\
\hline $\mathrm{R} 2$ & 600.3 & 547.7 & \\
\hline R3 & 628.1 & 573.0 & \\
\hline $\mathrm{R} 4$ & 520.2 & 474.5 & \\
\hline R5 & 531.8 & 485.1 & \\
\hline R6 & 361.8 & 330.1 & \\
\hline R7 & 358.9 & 327.4 & \\
\hline R8 & 487.5 & 444.7 & \\
\hline R9 & 414.0 & 377.6 & \\
\hline R10 & 79.9 & 72.9 & \\
\hline R11 & 318.6 & 290.6 & \\
\hline R12 & 81.8 & 74.7 & \\
\hline R13 & 794.8 & 725.1 & \\
\hline R14 & 350.0 & 319.3 & 192.0 \\
\hline R15 & 197.0 & 179.7 & \\
\hline R16 & 375.3 & 342.3 & 605.0 \\
\hline $\mathrm{R} 17$ & 110.8 & 101.1 & \\
\hline R18 & 130.0 & 118.6 & 62.0 \\
\hline R19 & 150.0 & 136.8 & 46.0 \\
\hline R20 & 145.2 & 132.4 & \\
\hline R21 & 304.0 & 277.3 & 270.0 \\
\hline
\end{tabular}

\begin{tabular}{|c|c|c|c|}
\hline Gully & $\begin{array}{c}\text { Length } \\
{[\mathrm{m}]}\end{array}$ & $\begin{array}{c}\text { Estimated } \\
\text { volume }\left[\mathrm{m}^{3}\right]\end{array}$ & $\begin{array}{c}\text { Measured } \\
\text { volume }\left[\mathrm{m}^{3}\right]\end{array}$ \\
\hline R22 & 179.3 & 163.5 & \\
\hline R23 & 74.9 & 68.4 & \\
\hline R24 & 103.4 & 94.3 & \\
\hline R25 & 364.9 & 332.9 & \\
\hline R26 & 93.3 & 85.1 & \\
\hline R27 & 65.2 & 59.4 & \\
\hline R28 & 145.8 & 133.1 & \\
\hline R29 & 180.4 & 164.5 & \\
\hline R30 & 65.9 & 60.1 & \\
\hline R31 & 192.6 & 175.7 & \\
\hline R32 & 39.9 & 36.4 & \\
\hline R33 & 69.4 & 63.3 & \\
\hline R34 & 98.2 & 89.6 & \\
\hline R35 & 117.3 & 107.0 & \\
\hline R36 & 124.7 & 113.7 & \\
\hline R37 & 163.2 & 148.9 & \\
\hline R38 & 104.7 & 95.5 & \\
\hline R39 & 37.6 & 34.3 & \\
\hline R40 & 197.6 & 180.3 & \\
\hline Total & 10197.7 & 9303.3 & \\
\hline & & & \\
\hline
\end{tabular}


average width of the gully, in the catchment area of 138 ha 3.6 ha of undergrowth was taken away due to skidding. The field observations reveal that only small front parts of gullies have the capacity to self-regenerate due to succession. In the more remote parts of the gully route the erosion processes take place resulting in soil flow down which excludes this area from forest production.

The main problem related to the erosion gullies caused by exploitation of forests is the soil erosion. Ten kilometres of gullies which were found on the 138 ha of the catchment area testify to the intensity of skidding work in this area. According to (Poesen et al. 2003) the investigation carried out in the watershed of Bystra (the Żywiec Beskids) showed that this 420 ha catchment contained more than $4 \mathrm{~km}$ of gullies. In this area most of the gullies were formed due to horse skidding.

Among the tested gullies the lowest volume of running meter was found for the V type gully (R34) and the highest volume for gully R19 - 1,613 $\mathrm{m}^{3} / \mathrm{m}$ (Tab. 2). In the work mentioned earlier (Pierzgalski and Popek 2002) that value amounted to approximately $1.35 \mathrm{~m}^{3}$ per running meter. The measurements were taken on $13 \%$ of the inventoried gullies. Taking into account the differentiation of the gullies in length and depth it may be stated that the selected gullies are representative for the investigated catchment. The mean depth of one running meter of gully was found to be 0,891 $\mathrm{m}^{3}$. On this basis it can be assumed that the total volume of soil and rock material removed from the catchment area due to erosion accelerated by skidding amounted to $9,303 \mathrm{~m}^{3}$ (Tab. 1). Taking into account that skidding activities have been performed for six years we can assume that the annual volume of the soil material removed from the catchment amounted to $1500 \mathrm{~m}^{3} /$ ha. For comparison, under natural conditions in the French Southern Alps, where the brittleness of the Jurassic black marl terrains renders them prone to intense gully erosion, this value amounted up to $100 \mathrm{~m}^{3} /$ ha (Mathys et al. 2003).

The volume of deeper gullies increased with the rate of $10 \%$ per year and in shallow gullies this decrease was twice lower (Tab. 3). From the deepest gully above $50 \mathrm{~m}^{3}$ of soil was removed during one year. Figure 5 shows that due to erosion process in gully no 19, from which the material is accumulated in the shallower segments, deepening of the deeper segments takes place. It may result from the lack of intensive or torrential rainfall.

\section{Conclusions}

Among the most common types of damages caused to forest ecosystems during skidding are soil disturbance and soil compaction which may increase the potential for erosion, retard the growth of residual trees and interfere with regeneration, and damage to residual trees and other vegetation which may slow down forest recovery and reduce the volume and quality of timber available for the subsequent harvest (Dykstra and Heinrich 1996).

Table 2. Characteristic of gullies with the established cross sections

\begin{tabular}{|c|c|c|c|c|}
\hline No of gully & $\begin{array}{c}\text { Length } \\
{[\mathrm{m}]}\end{array}$ & $\begin{array}{c}\text { Volume } \\
{\left[\mathrm{m}^{3}\right]}\end{array}$ & $\begin{array}{c}\text { Volume of one } \\
\text { running meter } \\
{\left[\mathrm{m}^{3}\right]}\end{array}$ & Type of gully \\
\cline { 1 - 3 } R14 & 350 & 192 & 0.549 & \multirow{2}{*}{ "W" gully } \\
\cline { 1 - 3 } R16 & 375 & 605 & 1.613 & \\
\hline R19 & 150 & 46 & 0.307 & \\
\hline R21 & 304 & 270 & 0.888 & \multirow{2}{*}{ ”V" gully } \\
\hline R18 & 129 & 52 & 0.403 & \\
\hline R34 & 98 & 33 & mean & \\
\hline
\end{tabular}

Table 3. Erosion rate of deep and shallow gullies

\begin{tabular}{|c|c|c|c|c|}
\hline \multirow{2}{*}{ No of gully } & Year & $\begin{array}{c}\text { Volume of one } \\
\text { running meter } \\
{\left[\mathrm{m}^{3}\right]}\end{array}$ & $\begin{array}{c}\text { Total volume } \\
{\left[\mathrm{m}^{3}\right]}\end{array}$ & $\%$ \\
\hline \multirow{3}{*}{ R_14 } & 2011 & 0.539 & 175.274 & \\
\cline { 2 - 5 } & 2012 & 0.550 & 192.469 & 10 \\
\cline { 2 - 5 } & soil loss & & 17.20 & 9 \\
\hline \multirow{3}{*}{ R_16 } & 2011 & 1.48 & 553.82 & \\
\cline { 2 - 5 } & 2012 & 1.61 & 605.04 & \\
\hline \multirow{2}{*}{ R_19 } & soil loss & & 51.23 & \\
\cline { 2 - 5 } & 2011 & 0.309 & 46.392 & 5 \\
\cline { 2 - 5 } & 2012 & 0.325 & 48.765 & 2.37 \\
\hline
\end{tabular}




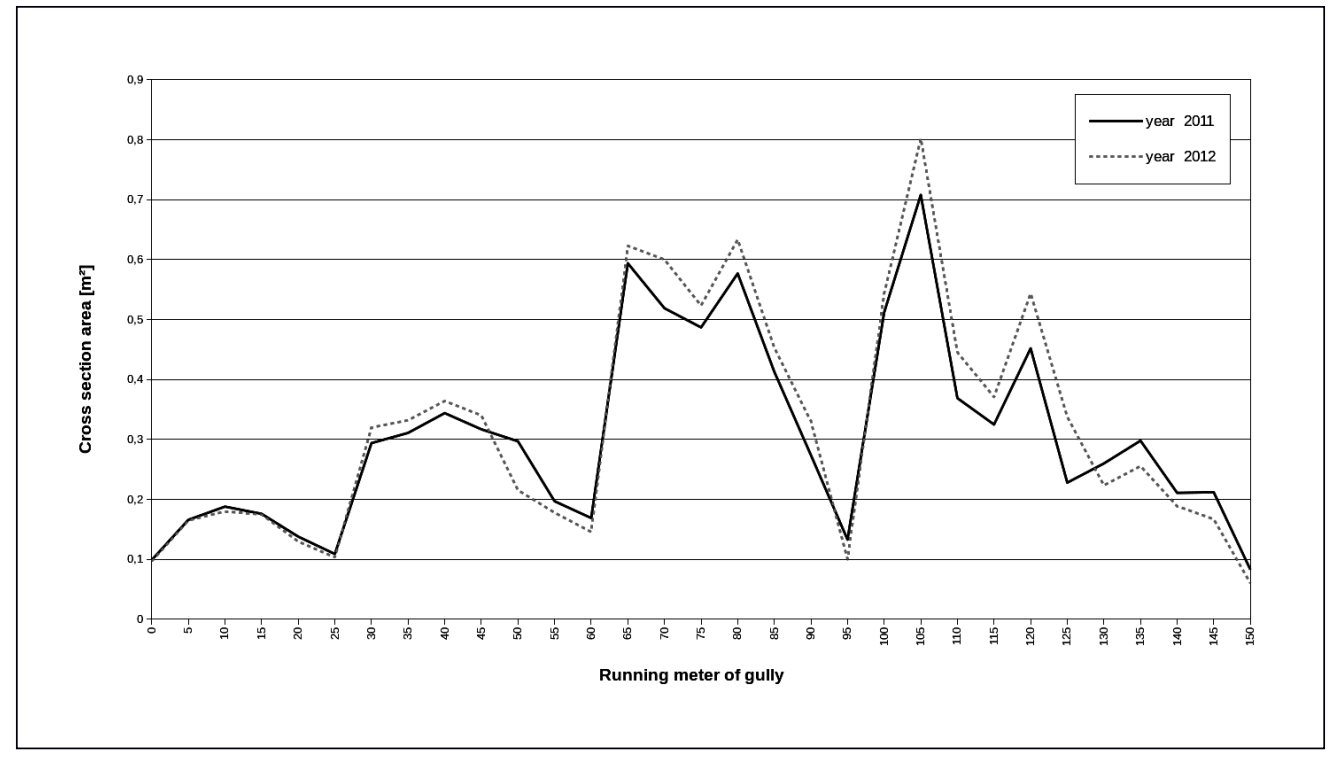

Fig. 5. Erosion rate of a shallow gully - R19

The presented data show that use of heavy equipment for skidding in mountain forests intensifies the erosion processes. Field observation has shown that even a few rides of skidder can begin the erosion process on the mountain slope leading to the formation of the "W" shape gullies which in comparison to "V" shape gullies leads to the increase of the soil material carried away from the catchment.

Taking into consideration further long-time activities connected with forest reconstruction combined with felling of big volume of trees in the Beskid Mountains it is evident that such activities should be duly controlled by the forest services. The best practices should include:

- planning of new skidding trails taking hydrological and soil properties of the region into consideration

- all skidding routes should possess the infrastructure preventing the soil from erosion

- skidding routes that are no longer used should be protected against further erosion.

\section{References}

Bakker, M.M., Govers, G. \& Rounsevell, M.D.A. (2004). The crop productivity-erosion relationship: an analysis based on experimental work, Catena, 57, pp. 55-76.

Boardman, J. \& Poesen, J. (2006). Soil erosion in Europe: major processes, causes and consequences, in: Soil Erosion in Europe, Boardman, J. \& Poesen, J. (Eds.). Wiley, Chichester 2006, pp. 479-487.

Bytnerowicz, A., Godzik, S., Poth, M., Anderson, I., Szdzuj, J., Tobias, C., Macko, S., Kubiesa, P., Staszewski, T. \& Fenn, M. (1999). Chemical composition of air, soil and vegetation in forests of the Silesian Beskid Mountains, Poland, Water Air \& Soil Pollution, 116, pp. 141-150.

CEC (2006). Proposal for a Directive of the European Parliament and of the Council establishing a framework for the protection of soil and amending Directive 2004/35/EC. Brussels, 22.9.2006, COM (2006) 232 final, 2006/0086 (COD).

Cerdan, O., Govers, G., Le Bissonnais, Y., Van Oost, K., Poesen, J., Saby, N., Gobin, A., Vacca, A., Quinton, J., Auerswald, K., Klik, A., Kwaad, F.J.P.M., Raclot, D., Ionita, I., Rejman, J., Rousseva, S., Muxart, T., Roxo, M.J. \& Dostal, T. (2010). Rates and spatial variations of soil erosion in Europe: A study based on erosion plot data, Geomorphology, 122, 1-2, pp. 167-177.

Dykstra, D.P. \& Heinrich, R. (1996). FAO model code of forest harvesting practice, Food and Agriculture Organization of the United Nations, Rome, Italy 1996.

Gyssels, G. \& Poesen, J. (2003). The importance of plant root characteristics in controlling concentrated flow erosion rates, Earth Surface Processes and Landforms, 28, pp. 371-384.

Gyssels, G., Poesen, J., Bochet, E. \& Li, Y. (2005). Impact of plant roots on the resistance of soils to erosion by water: a review, Progress in Physical Geography, 29(2), pp. 1-28.

Mathys, N., Brochot, S., Meunier, M. \& Richard, D. (2003). Erosion quantification in the small marly experimental catchments of Draix (Alpes de Haute Provence, France). Calibration of the ETC rainfall-runoff-erosion model, Catena, 50, pp. 527-548.

Moir, W.H., Ludwig, J.A. \& Scholes, R.T. (2000). Soil erosion and vegetation in grasslands of the Peloncillo Mountains, New Mexico, Soil Science Society of America Journal, 64, pp. 1055-1067.

Pierzgalski, E. \& Popek, Z. (2002). Hydraulic aspects of planning skidding paths in mountain areas, Czasopismo Techniczne. Inżynieria Środowiska, 5, pp. 55-62, ISSN 0011-4561. (in Polish)

Poesen, J., Nachtergaele, J., Verstraeten, G. \& Valentin, C. (2003). Gully erosion and environmental change: importance and research needs, Catena, 50, pp. 91-133.

RDLP Katowice (2014). Mapa Lasów. (http://mapa.katowice.lasy. gov.pl/(20.12.2015))

Stavi, I., Perevolotsky, A. \& Avni, Y. (2010). Effects of gully formation and headcut retreat on primary production in an arid rangeland: Natural desertification in action, Journal of Arid Environments, 74, pp. 221-228.

Valentin, C., Poesen, J. \& Yong, L. (2005). Gully erosion: impacts, factors and control, Catena, 63, pp. 132-153.

Zheng, F., He, X., Gao, X., Zhang, C. \& Tang, K. (2005). Effects of erosion patterns on nutrient loss following deforestation on the Loess Plateau of China, Agriculture Ecosystems and Environment, 108, pp. 85-97.

\section{Acknowledgment}

This research was supported by the Polish Ministry of Science and Higher Education, grant No. N N309 193037 and by the EnvEurope Life + LIFE08 ENV/IT/000399 project. 


\section{Procesy erozji zapoczątkowane przez użycie ciężkiego sprzętu w górskich lasach zlewni Wilczego Potoku w Beskidzie Śląskim}

Streszczenie: W ciągu ostatniej dekady, w Beskidzie Śląskim, zaobserwowano zmiany w gospodarce leśnej spowodowane wprowadzeniem ciężkiego sprzętu do prac leśnych, głównie do zrywki drewna. W artykule przedstawiono wyniki trzech lat badań rynien erozyjnych powstających w lesie górskim po zrywce wykonanej przy stosowaniu ciężkiego sprzętu. W zlewni Wilczego Potoku, o powierzchni powyżej 100 ha zinwentaryzowano 40 rynien erozyjnych. Pomiar długości i głębokości wąwozy wykazały, że całkowita objętość gleby i materiału skalnego usuniętego ze zlewni w wyniku erozji - przyspieszonej przez prace zrywkowe - wynosi ponad $9000 \mathrm{~m}^{3}$. Roczne tempo erozji rynien zrywkowych wynosi 10\%. Przedstawione wyniki pokazują, że niezbędne jest podjęcie działań ochronnych i zastosowanie środków zapobiegawczych w celu ograniczenia procesów degradacji gleby. 